\title{
ДОСВІД ЗМІШАНОГО НАВЧАННЯ УКРАЇНСЬКОЇ МОВИ ЗА ПРОФЕСІЙНИМ СПРЯМУВАННЯМ У ЗВО
}

\author{
Катерина Денисюк \\ кандидат філологічних наук, доцент кафедри лінгвістики \\ Донбаський інститут техніки та менеджменту ПВНЗ «Міжнародний науково- \\ технічний університет імені академіка Юрія Бугая» \\ м. Краматорськ, Україна \\ ORCID ID 0000-0002-9946-8302 \\ katerinka05.06.1991@gmail.com
}

\begin{abstract}
Анотація. У статті розкрито досвід викладання навчальної дисципліни «Українська мова за професійним спрямуванням» в українському виші, що працює за системою змішаного навчання. Розглянуто переваги зазначеної форми навчання при роботі зі студентами за принципами менторської підтримки здобуття освіти. Окреслено складнощі, які виникають у процесі викладання та особливості адаптації зарубіжного досвіду освітнього процесу в умовах вітчизняного сьогодення. Наведено результати опитування здобувачів освіти щодо їх ставлення до такого виду взаємодії з педагогом та форми навчання. У розвідці запропоновано вирішення проблемних ситуацій у поєднанні аудиторних та позааудиторних занять, наведено приклади засобів навчання під час онлайн навчання української мови студентів різних спеціальностей, які дозволять гармонізувати поєднання обох видів занять.
\end{abstract}

Ключові слова: змішане навчання; українська мова; комунікативна підготовка; професійна підготовка; менторська підтримка.

Постановка проблеми в загальному вигляді. Зміни, що відбулися в системі освіти на початку минулого року спричинили необхідність перегляду навчальних програм у ЗВО. На сьогодні проведення частини занять онлайн вже не сприймається як тимчасові заходи, а являє собою майбутнє освітнього простору. Цифровізація навчальних дисциплін передбачає не тільки зміни у засобах навчання, але і у системі взаємодії учасників освітнього процесу.

У Донбаському інституті техніки та менеджменту запроваджено систему змішаного навчання 3 чергуванням форм проведення занять в аудиторіях та дистанційно, яка випробувала себе у попередньому навчальному році. 3 переходом до системи змішаного навчання відбулися також зрушення у системі кураторського та викладацького контролю, що трансформувалися у створення менторської платформи. За умови неможливості щоденного наставництва під час перебування в інституті було вирішено перейняти світовий досвід менторської підтримки навчання, що передбачає персональну відповідальність студента в процесі здобуття освіти. Викладачі перестали бути так званим «керуючим і карним» органом, стали більш відкритими для кожного студента 
особисто, готовими до надання консультацій упродовж усього процесу викладання дисципліни як проблемно-пошукового проєкту. Такий досвід роботи показав як позитивні зрушення, так і ускладнення, які ще потребують вирішення. Обидва аспекти стали підгрунтям для запропонованої розвідки.

Аналіз останніх досліджень i публікацій. Дослідження системи змішаного навчання $\epsilon$ новою темою у наукових пошуках, яка почала активно розроблятися ще декілька років тому. Про використання моделі змішаного навчання писали В. Бацуровська, Є. Желнова, В. Кухаренко, I. Максак, Н. Осипова, Л. Петухова, Н. Рашевська, О. Спірін та інші. Серед англомовних розвідок виділяємо роботи Т. Вандерарка, який розкриває переваги змішаного навчання для педагога та Ф. Бікертона, який наводить аргументи про те, що ми вже готові до нової форми роботи. І вітчизняні, і зарубіжні автори намагаються висвітлити переваги та недоліки такої форми освітнього процесу, що свідчить про актуальність проблеми та потребу iї глибшого вивчення. Наприклад, О. Коротун запропонувала таке визначення: «під терміном «змішане навчання» в межах нашого дослідження розуміємо цілеспрямований процес взаємодії суб'єктів навчання, в якому поєднані традиційна та дистанційна моделі навчання, відбувається в аудиторії та поза ії межами, у синхронному та асинхронному режимах, базується на широкому використанні ІКТ». (Коротун, 2016). Т. Муращенко змішане навчання розуміє як «педагогічно виваженого поєднання технологій традиційного, електронного, дистанційного та мобільного навчання, спрямованого на інтеграцію аудиторного та позааудиторного навчання» (Муращенко, 2017). Ми погоджуємось із думкою про те, що поєднання дистанційного і аудиторного навчання $є$ закономірним розвитком системи освіти у сучасних умовах. Проте явище менторської підтримки у цій трансформації потребує подальших грунтовних досліджень, оскільки на теперішній час спостерігаємо недостатню підготовку до переходу на новий рівень співпраці з позицій усіх учасників процесу навчання.

Формулювання цілей статті (постановка завдання). Розкриття питання висвітлення досвіду викладання навчальної дисципліни «Українська мова за професійним спрямуванням» передбачало: 1) опис системи змішаного навчання, що функціонує в Донбаському інституті техніки та менеджменту; 2) опис системи менторської підтримки за якою здійснюється процес викладання, окреслення ускладнень, що виникають при засвоєнні зарубіжного досвіду вітчизняними учасниками освітнього процесу; 3) виявлення переваг і недоліків змішаного навчання з позиції викладачів і студентів та запропонування можливих шляхів їх вирішення на прикладі викладання дисципліни «УМЗПС». 
Досвід змішаного навчання української мови за професійним спрямуванням у ЗВО

Методика дослідження ставлення здобувачів освіти до змішаного навчання, виявлення позитивних та негативних аспектів складалася із аналізу результатів опитування за допомогою анкетування випадкової вибірки респондентів серед загальної кількості студентів.

Результати дослідження. Змішане навчання як спосіб навчання студентів у Донбаському інституті техніки та менеджменту відбувається на засадах менторської підтримки, що переводить процес співпраці зі здобувачами освіти у нову площину. Такий підхід переносить досвід провідних університетів світу на українську дійсність і потребує відповідної адаптації. По-перше, це подолання бар'єрів, які виникли внаслідок традиційного викладання у ЗВО. Комунікативна орієнтація дисципліни «Українська мова за професійним спрямуванням» $\epsilon$ пріоритетним аспектом, тоді як студенти мають багато упереджень та страхів припуститися помилки і отримати низькі бали внаслідок цього, що заважає процесу спілкування з викладачем. Змішане навчання передбачає виконання позааудиторних завдань на розвиток зв'язного мовлення (підготувати повідомлення про майбутню професію, підготувати виступ для наради з фаху тощо), результатом яких $є$ створення аудіозаписів. У такий спосіб надається можливість поступового звикання до публічних виступів - від підготовленої, відрепетируваної промови до спонтанної, від аудіоповідомлень до виступу перед аудиторією. Робота викладача у цьому процесі передбачає спрямовування i мотивування студентів до вивчення професійної лексики, опанування прийомів професійного спілкування, підтримка зворотнього зв'язку, віднаходження суміжних тем для здобувачів освіти різних спеціальностей, що навчаються разом. По-друге, перехід до нових засобів навчання. Використання освітніх сервісів та платформ виходить на перший план, тому дуже важливо обрати завдання із зрозумілим способом виконання. У цьому випадку важливо не обмежуватись тестовими формами, які мають значну кількість переваг для викладача (не треба витрачати час на перевірку, респонденти автоматично після заповнення отримують результати тощо), але позбавляють можливості розвитку креативності студентів. Під час позааудиторних занять з української мови це можуть бути професійно орієнтовані онлайн-конференції, аудіо- та відеоповідомлення, робота 3 презентаціями тощо. У цьому випадку важливо дотримуватись правил кібербезпеки, оскільки створення спільного простору полегшує доступ до особистої інформації, а тому задача викладача-ментора допомогти організувати зберігання приватної інформації окремо від навчальної, запропонувати такий варіант спільного простору, який дозволить учасникам спілкуватись і обмінюватись даними з навчальною метою, підтримати ініціативи 
створення власних чатів і мереж, висвітлити особливості і відповідальність під час цифрової комунікації. По-третє, важливим є об’єднання онлайн та офлайн навчання в єдину систему, чому частково стають на заваді проблеми, висвітлені у першому питанні. Традиційна модель аудиторних занять, до якої звикли теперішні студенти, впливає на відчуття так званої другорядності занять, що проводяться онлайн. 3 боку викладача це вимагає особливої побудови низки занять у такий спосіб, щоб навчальний матеріал онлайн зустрічей був відповіддю на запитання, поставлені офлайн, і навпаки. Крім того, ми відступаємо від класичних лекцій, відводячи більше часу на самостійну роботу, стимулюючи пошуково-дослідницьку роботу студентів. Наприклад, під час вивчення побудови документів ми говоримо про структуру, вказуючи тільки назви реквізитів, а потім пропонуємо відшукати в мережі зразки, які відповідають опрацьованій схемі, і приклади іï порушення; пропонуємо переробити наявні у вільному доступі зразки відповідно до поставленого завдання тощо. Почетверте, важливим є приведення переважної кількості здобувачів освіти (прагнемо всіх) до єдиного рівня мотивації і усвідомлення змішаної системи навчання. Так, спостерігаємо, що студенти заочного відділення легше сприймають поєднання двох видів занять, та швидше показують високий результат засвоєння навчального матеріалу, ніж студенти денної форми навчання, які зорієнтовані більшою мірою на офлайн заняття. Виходом з такої ситуації $є$ моніторинг контролю знань після онлайн занять. При викладанні «Української мови за професійним спрямуванням» використовуємо аудиторний робочий час для опанування матеріалу з курсу, а позааудиторний з метою покращення рівня володіння нормами літературної мови (переважно орфографічними, стилістичними, синтаксичними). По-п'яте, відповідна підготовка педагогів-менторів, що вимагає відповідного навчання, самоосвіти i готовності до збільшення взаємодії зі студентами. Змішане навчання не зменшує, а збільшує обсяг спілкування між учасниками освітнього процесу, оскільки цифровізація навчання зменшила (майже повністю витіснила) формат, коли педагог просто подає новий матеріал. Тепер викладач допомагає опанувати матеріал, який студенти вже бачили і спробували опрацювати матеріал, надісланий до початку заняття у вигляді презентацій, відеолекцій, посилань на електронні матеріали тощо. Такий спосіб по суті є трансформацією проблемнопошукового навчання, коли педагог-ментор не вчить «з нуля», а обговорює матеріал для виявлення складних моментів, їх більш детального розгляду і пояснення в разі потреби. Крім того, взаємодія тепер не обмежується робочим часом в інституті, здобувачі освіти можуть звертатися за підтримкою i 
допомогою у будь-який час через електронну пошту, месенджери, спілкуватися особисто, що вимагає відкритості та комунікабельності викладача.

Серед переваг змішаного навчання ми виділяємо збільшення можливостей та інтенсивності навчання шляхом цифровізації освіти. Якщо раніше доводилось витрачати частину аудиторного часу для демонстрації наочного матеріалу, його опрацювання, то сьогодні ми маємо змогу подати цей матеріал заздалегідь, обговорити його на онлайн конференції, використовуючи значно більшу кількість сервісів, ніж це можливо на офлайн занятті. Набагато знизився рівень так званої паперової роботи, коли потрібно підготувати індивідуальні завдання для студентів (ніяких роздруківок для наочності, роздавання різних варіантів завдань). Також це заощаджує час на перевірку завдань, які можна опрацювати за допомогою сервісів. Наприклад, використання гугл форм у режимі відправки результатів після ручної перевірки дозволяє перевіряти тільки ті завдання, на які передбачена розгорнута відповідь (виправити помилки, навести приклади, перелічити складові тощо), а всі інші підраховуються автоматично, і що важливо, позбавляє необхідності оприлюднення результатів завдяки відправці результатів тільки респонденту. Змішане навчання розкриває можливості для здобуття освіти у зручній і безпечній обстановці, коли знижується рівень тривожності через перебування серед значної кількості людей, студенти концентрують увагу на навчальному матеріалі, мають можливість записати відеоконференцію, щоб переглянути іiі повторно, не виголошуючи прохання повторити чи додатково пояснити матеріал (або робити це, звертаючись особисто до викладача). Ще один бонус такого типу навчання для викладача - можливість подати матеріал значній кількості студентів, що дозволяє переглянути розклад занять - зменшити години для подачі теоретичного матеріалу та збільшити час практично орієнтованих занять, виділити години для роботи в малих групах, що не передбачено програмою для навчальної дисципліни «Українська мова за професійним спрямуванням».

Опитування студентів показало, що більшість (70\% опитуваних) вважає перевагою змішаного навчання безпечність через відсутність перебування серед значної кількості людей, що свідчить про рівень свідомості молоді за теперішніх реалій. На другому місці (60\% респондентів) опинився показник зручності вивчення матеріалу, що засвідчує про розрив традиційних засобів навчання із сьогоднішніми студентами, для яких цифровий контент сприймається краще та легше ніж попередниками. Це підтверджує і той факт, що 30\% студентів засвідчили більш доступне викладання за допомогою сучасних технологій. Важливим для здобувачів освіти стала можливість поєднання роботи та 
навчання, оскільки онлайн заняття заощаджують час, дозволяють переглянути їх у відеозаписі у зручний час. Такий підхід до навчання підтримується системою менторського супроводу процесу освіти, оскільки важливим $\epsilon$ не факт присутності на аудиторних чи позааудиторних годинах, а якість засвоєння матеріалу.

Недоліками для викладача при роботі за системою змішаного навчання вважаємо погіршення рефлексії уваги здобувачів освіти під час онлайн занять. Маємо на увазі, що дистанційний робочий час передбачає постійне поточне опитування реакцій студентів на матеріал, що опрацьовується. Вирішенням такого типу ускладнень вбачаємо створення шаблонів опитувальників до початку онлайн занять, що дозволить заощаджувати час на проведення рефлексії. Додатково ускладнюється втілення особистісно орієнтованого навчання за умови значної кількості учасників конференцій. Такі труднощі виникають здебільшого при заняттях позааудиторних і потребують збільшення уваги педагога при офлайн зустрічах. Це спонукає до додаткового спілкування зі здобувачами освіти в позаробочий час, а також цьому сприяє недостатньо глибоке осмислення студентами принципів менторської підтримки. Можливим виходом 3 подібних проблемних ситуацій вбачаємо проведення тренінгів 3 питань менторства для всіх учасників такої форми співпраці у ЗВО, коли викладачі вчитимуться відкритості до спілкування зі студентами, а студенти ставатимуть більш мотивованими до самостійного розв'язання проблемних питань, пошукової діяльності тощо. Під час викладання курсу «Українська мова за професійним спрямуванням» складнощі викликають проведення співбесід, усних опитувань та інших перевірених часом усних видів робіт на заняттях, що проводяться онлайн. Також викликає незручності перевірка письмових робіт, оскільки друкування відповідей за допомогою електронних пристроїв з одного боку автоматично виправляє орфографічні помилки, а з іншого збільшує кількість описок. Для вирішення цих питань необхідно повністю переробити систему навчальних матеріалів і завдань, щоб дібрати ефективні форми і засоби навчання відповідно до затвердженого розкладу занять студентів.

Опитування студентів показало, що для студентів денної форми навчання (56,7\% респондентів) негативним вбачається збільшення кількості матеріалу для самостійного опрацювання, що свідчить про недостатне розуміння здобуття освіти за системою менторської підтримки, а також про непідготовленість до проблемно-пошукового підходу. Респонденти, які дали таку відповідь мають інші очікування щодо процесу навчання у ЗВО, потребують участі у відповідних мотиваційних заходах і тренінгах, що сприятиме більш усвідомленому погляду на отримання вищої освіти молоддю. Майже однакова кількість опитуваних (46 
і 43 відсотки відповідно) дали відповідь про недостатню взаємодію з викладачем та ускладнення спілкування, що засвідчує потребу в офлайн комунікації. Такі вподобання суперечать безпеці у період епідеміологічної загрози, але на сьогодні не мають варіантів для вирішення. За умови змін у теперішній ситуації i повернення традиційних форм навчання доцільним вбачається збереження частини онлайн занять/завдань для підтримки зручності викладання матеріалу у такий спосіб, про що здобувачі освіти засвідчили у перевагах змішаного навчання.

\section{Висновки 3 дослідження і перспективи подальших розвідок у цьому} напрямі. Опрацювання окреслених завдань дослідження показало, що освітній процес у теперішньому стані - це перехідний етап курсу на цифровізацію освіти. Опанування технічної складової змішаної форми навчання не викликає питань чи труднощів серед учасників освітнього процесу. У цей же час існує проблема усвідомлення нової форми взаємодії зі студентами серед викладачів, що потребує змін у системі спілкування, більшої відкритості та гнучкості графіку роботи. Серед студентів поширеною є проблема недостатньої мотивації до самостійної проблемно-пошукової роботи, яка передбачається змішаною формою навчання. Вирішення обох проблем вбачається у залученні фахівців 3 питань менторства, цифрової освіти до проведення тренінгів та курсів для всіх учасників освітнього процесу.

Подальшого вивчення, перш за все, потребує питання менторства як форми співпраці зі здобувачами освіти у ЗВО, оскільки перенесення його принципів на теперішній стан освітнього процесу передбачає зміни у мотиваційній сфері. Викладачі переосмислюють спілкування на більш відкрите і партнерське, що означає не такий чіткий поділ на робочий і позаробочий час. Студенти стають більше мотивованими на отримання досвіду в процесі вирішення проблемнопошукових завдань, а не на отримання готової відповіді. Така форма взаємодії не тільки змінює процес спілкування, але і значно впливає на якість та інтенсивність отримання знань у ЗВО. Важливим вважається і розробка, вдосконалення, адаптація дидактичних засобів навчання відповідно до вимог цифровізації освіти і змішаної форми навчання. Розв'язання потребують складнощі викладання української мови під час онлайн занять, зокрема навчання нормам літературної мови, які передбачають усну роботу.

\section{СПИСОК ВИКОРИСТАНИХ ДЖЕРЕЛ}

1. Коротун, О. (2016). Методологічні засади змішаного навчання в умовах вищої освіти. Інформаційні технології в освіті, № 3(28), 117-129.

Професіоналізм педагога: теоретичні й методичні аспекти. Методичні матеріали до проєкту «Цифровий освітній простір: українсько-польський досвід». - Слов’янськ, 2021. 


\title{
К. ДЕНИСЮК
}

Досвід змішаного навчання української мови за професійним спрямуванням у ЗВО

2. Кухаренко, В. (2012). Про систему дистанційногонавчання у відкритому дистанційному курсі. Інформаційні технологї в освіті, 11, 32-42

3. Муращенко, Т. (2017). Змішане та дистанційне навчання як спосіб доступу до якісної освіти Відкрите освітнє е-середовище сучасного університету, 3. Взято 3 http://nbuv.gov.ua/UJRN/oeeemu_2017_3_45

4. Петухова, Л. (2010). Електронна система підтримки нормативно-правової бази дистанційної системи навчання. Інформаційні технології в освіті, 7, 12-18.

5. Рашевська, Н. (2011). Програмні засоби мобільного навчання. Інформаційні технологіï $i$ засоби навчання, 1 (21). Взято 3 http://www.nbuv.gov.ua/ejournals/ITZN/2011_1/Rashevska.pdf

6. Blended Learning: 10 Trends. (2014) Взято 3 http://www.dreambox.com/blog/blendedlearning-10-trends

7. Bickerton, P. (2015). 7 Reasons Blended Learning is The Future of Training. Взято 3 http://trainingstation.walkme.com/7-reasons-blended-learning-futuretraining/

8. Vander Ark., T. (2011). 10 Reasons Teachers Love Blended Learning. Взято 3 http://www.huffingtonpost.com/tom-vander-ark/10-reasons-teachers-love-_b_894222.html

\section{THE EXPERIENCE OF BLENDED LEARNING UKRAINIAN LANGUAGE FOR PROFESSIONAL PURPOSES IN THE HIGHER EDUCATION}

\author{
Kateryna Denysiuk \\ Candidate of Philological Sciences, \\ Associate Professor of the Linguistics Department, \\ Donbas Institute of Technology and Management, \\ PHEI "Academician Yuriy Bugay International Scientific and Technical University” \\ Kramatorsk, Ukraine \\ ORCID ID 0000-0002-9946-8302 \\ katerinka05.06.1991@gmail.com
}

\begin{abstract}
Distance education today is especially relevant in the field of training young people with a different age and different motives of education. The structure of online and fulltime learning forms, trends in the implementation of blended learning need be analyzed, becouse of such reasons: 1) the changes have taken place in the educational information structure of modern society; 2) the relevance of the development and implementation of new educational services based on ICT and remote technologies; 3 ) the necessity of mobility of students and teachers.

In turn informatization can effectively develop pedagogical technology as blended learning . So, such authors as O. Spirin, Yu. Tryus, Ye. Zhelnova work in researching this problem. The actual problem is the use of blended learning technologies in modern Ukrainian university. Researchers as V. Kukharenko or B. Shunevich have much articles of brighting problem.

The experience of blended learning Ukrainian language for professional purposes in Donbass institute of technology and management shows the benefits and complication of this learning form. We analyze the concept of blended learning, put forward methodological approaches for underpin the process of learning in higher education with the use of blended learning models.

The article is developed model of blended learning in a higher education. The described methods and forms of organizing and tools used in the blended learning and advantages of this learning model. The interactive teaching methods in the online and fulltime lessons of the discipline "Ukrainian Language for professional purposes" is suggested. The results of students Interviewing show their readiness for blended learning in constant time.
\end{abstract}

() ДВНЗ «Донбаський державний педагогічний університет» 


\section{К. ДЕНИСЮК}

Досвід змішаного навчання української мови за професійним спрямуванням у ЗВО

Online learning as part of blended learning can be considered as a means of modernizing the education system. The readiness of students for independent study should be developed by trainings and courses. The teachers are prepared for blended learning better, but need to be more open for communication.

Key words: blended learning; Ukrainian language; communicative training; professional training; mentoring support.

\section{REFERENCES}

1. Korotun, O. Methodological bases of blended learning in the higher education. Information Technologies in Education, № 3(28), 117-129.

2. Kukharenko, V. About the distance learning system in open distance course. Information Technologies in Education, 11, 32-42.

3. Murashchenko, T. Blended and distance learning as a way of access to quality education. Open educational e-environment of a modern university Retrieved from: http://nbuv.gov.ua/UJRN/oeeemu_2017_3_45.

4. Petukhova, L. Electronic system of support of normative-legal base of distance learning system. Information Technologies in Education, 7, 12-18. Retrieved from http://ite.kspu.edu/webfm_send/671.

5. Rashevska, N. V. (2011). Software for mobile mobility. Information Technologies in Education, 1 (21). Retrieved from: http://www.nbuv.gov.ua/ejournals/ITZN/2011_1/Rashevska.pdf (in Ukrainian).

6. Blended Learning: 10 Trends. (2014). Retrieved from http://www.dreambox.com/blog/blended-learning-10-trends

7. Bickerton, P. (2015). 7 Reasons Blended Learning is The Future of Training. Retrieved from http://trainingstation.walkme.com/7-reasons-blended-learning-futuretraining/

8. Vander Ark., T. (2011). 10 Reasons Teachers Love Blended Learning. Retrieved from http://www.huffingtonpost.com/tom-vander-ark/10-reasons-teachers-love-_b_894222.html

Матеріали надійшли до редакції 26.09.2021 р. 